\title{
Prevalence of pre-sarcopenia and sarcopenia in Hong Kong Chinese geriatric patients with hip fracture and its correlation with different factors
}

\author{
Angela WH Ho *, Mianne ML Lee, Eunice WC Chan, Heddy MY Ng, CW Lee, WS Ng, SH Wong
}

\section{A B S T R A C T}

Introduction: Sarcopenia and osteoporosis are age-related declines in the quantity of muscle and bone, respectively. Both contribute in disability, fall, and hip fracture in the elderly. This study reported the prevalence of sarcopenia in Chinese geriatric patients with hip fracture, and the correlation between relative appendicular skeletal muscle mass index and other factors.

Methods: This case series was conducted in Kowloon West Cluster Orthopaedic Rehabilitation Centre in Hong Kong. Data of all geriatric patients with primary hip fracture admitted to the above Centre from June to December 2014 were studied. Isometric grip strength, the maximal handgrip strength, was measured using a JAMAR hand dynamometer. Body composition including appendicular and wholebody lean body mass was measured using dualenergy X-ray absorptiometry. Pearson's correlation was used to examine the correlation between relative appendicular skeletal muscle mass index and other factors.

Results: A total of 239 patients with a mean age of 82 years were included in the study. Stratifying patients as male or female, the mean $( \pm$ standard deviation) hand grip strength was $20.6 \pm 7.3 \mathrm{~kg}$ and $13.6 \pm 4.5 \mathrm{~kg}$, the mean relative appendicular skeletal muscle mass index was $5.72 \pm 0.83 \mathrm{~kg} / \mathrm{m}^{2}$ and $4.87 \pm$ $0.83 \mathrm{~kg} / \mathrm{m}^{2}$, and the mean hip bone mineral density was $0.696 \pm 0.13 \mathrm{~g} / \mathrm{cm}^{2}$ and $0.622 \pm 0.12 \mathrm{~g} / \mathrm{cm}^{2}$, respectively. The prevalence of sarcopenia based on relative appendicular skeletal muscle mass index and hand grip strength according to the Asian Working
Group for Sarcopenia definition was $73.6 \%$ in males and $67.7 \%$ in females. According to the European
Working Group on Sarcopenia definition, the prevalence of pre-sarcopenia was $20.8 \%$ in males and $12.4 \%$ in females. Relative appendicular skeletal muscle mass index was positively correlated with hand grip strength, body weight, hip bone mineral density, body mass index, and total fat mass in males; and hand grip strength, body weight, body height, body mass index, and total fat mass in females. Except for body height in females, all correlations were statistically significant.

Conclusion: The prevalence of sarcopenia was very high in geriatric hip fracture patients, and much higher than that in community-dwelling elderly population. Apart from the need to prescribe osteoporosis medicine, sarcopenia screening and treatment should be offered and is essential to reduce subsequent fall, subsequent fracture, fracture-related complications and economic burden to Hong Kong.

\section{Hong Kong Med J 2016;22:23-9 \\ DOI: $10.12809 / \mathrm{hkmj} 154570$}

\author{
${ }^{1}$ AWH Ho *, FHKCOS, FHKAM (Orthopaedic Surgery) \\ ${ }^{2}$ MML Lee, BSc, MSc \\ ${ }^{2}$ EWC Chan, BSc, MSc \\ ${ }^{2} \mathrm{HMY} \mathrm{Ng}$, BSc, MSc \\ ${ }^{2} \mathrm{CW}$ Lee, BSc \\ ${ }^{2}$ WS Ng, BSc, MSc \\ SH Wong, FHKCOS, FHKAM (Orthopaedic Surgery) \\ ${ }^{1}$ Department of Orthopaedics and Traumatology \\ ${ }^{2}$ Department of Occupational Therapy \\ Caritas Medical Centre, Shamshuipo, Hong Kong \\ * Corresponding author: angelaho@alumni.cuhk.net
}

An earlier version of this paper was presented at WCO-IOF-ESCEO (World Congress on Osteoporosis, Osteoarthritis and Musculoskeletal Disease, International Osteoporosis Foundation) held in Milan, Italy on 28 March 2015.

New knowledge added by this study

- The prevalence of sarcopenia was alarmingly high in geriatric hip fracture patients, and was much higher than that in studies that reported sarcopenia in community-dwelling Chinese elderly population.

Implications for clinical practice or policy

Apart from surgical treatment of hip fracture, a well-structured screening and treatment programme for osteoporosis and sarcopenia should be implemented in order to reduce the subsequent fall risk and fracture risk.

\section{Introduction}

Ageing is associated with changes in all body organs including body composition, skeletal muscle, and bone mass. Muscle mass decreases by $3 \%$ to $8 \%$ per decade after the age of 30 years and the rate of decline is even higher after the age of 60 years. ${ }^{1-3}$ Rosenberg ${ }^{4}$ first referred to this involuntary agerelated loss of muscle mass as 'sarcopeny' in 1989. 


\section{香港老年顝骨骨折病人的前期肌少症和肌少症的 發病率以及其相關因素}

\author{
何穎恆、李美蓮、陳泳之、吳明英、李中華、吳穎思、黃仕雄
}

引言：肌少症和骨質疏鬆症分別指患者隨着年齡增長其肌肉量和骨骼 質量下降的情況。兩者都會造成老年人行動不便、跌倒與骨折。本文 報告有關香港老年顝骨骨折病人的肌少症發病率, 以及探討這發病率 與其相對骨骼肌質量指數（RASM）和其他因素的相關性。

方法：本研究回顧於2014年6月至12月期間到香港的九龍西聯網矯形 康復中心求診的原發性髖骨骨折的老年病人的紀錄。使用手握力測量 器量度患者的最大長握力。採用雙能X線吸收測量法量度包括闌尾和 全身的去脂體重。然後使用Pearson相關系數來研究RASM與其他因素 之間的關係。

結果：共239名患者被納入研究範圍, 他們平均年齡 82 歲。把患者分 為男女組別, 其手握力平均值 ( \pm 標準差 $)$ 分別為 $20.6 \pm 7.3 \mathrm{~kg}$ 和 13.6 $\pm 4.5 \mathrm{~kg} ; \mathrm{RASM}$ 的平均值分別為 $5.72 \pm 0.83$ 和 $4.87 \pm 0.83 \mathrm{~kg} / \mathrm{m}^{2}$; 顝 骨礦物密度的平均值分別為 $0.696 \pm 0.13$ 和 $0.622 \pm 0.12 \mathrm{~g} / \mathrm{cm}^{2}$ 。根據 RASM和亞洲肌少症工作小組對手握力的定義, 肌少症患病率分別為 男性 $73.6 \%$, 女性 $67.7 \%$ 。而按歐洲肌少症工作小組的定義, 前期肌少 症患病率分別為男性 $20.8 \%$, 女性 $12.4 \%$ 。男性患者中, RASM與手握 力、體重、髖部骨密度、身體質量指數和總脂肪量呈正相關; 而女性 患者中, RASM則與手握力、體重、身高、身體質量指數和總脂肪量 呈正相關。除了女性患者的身高, 以上均達統計學顯著相關性。

結論：肌少症在老年髖部骨折患者中的比率相當高, 比在社區居住的 老人更要高得多。除了須處方治療骨質疏鬆症的藥物, 亦應為患者提 供肌少症的篩查與治療。此舉非常重要, 因為能減少患者再跌倒或骨 折的機會, 並減低與骨折相關的併發症以及減少為香港帶來的經濟負 擔。 (strength or performance). ${ }^{16}$ The Working Group suggests three stages of sarcopenia: pre-sarcopenia stage, characterised by low muscle mass without change in muscle strength or performance; sarcopenia, low muscle mass plus low muscle strength or low physical performance; and severe sarcopenia, with a decrease in all three components: muscle mass, strength, and performance.

Inadequate protein intake is one of the main risk factors for sarcopenia. ${ }^{17}$ One study showed that the dietary intake of patients undergoing orthopaedic surgery was insufficient in terms of energy, proteins, and micronutrients. ${ }^{18}$ This situation is often due to a hypermetabolic state secondary to inflammation, to a reduced food intake due to lack of appetite and to patients being confined to bed. For all these reasons, the European Society for Parenteral and Enteral Nutrition recommends the use of nutritional supplements in older people who have experienced a hip fracture. ${ }^{19}$ A daily intake of 1.2 to $1.5 \mathrm{~g} / \mathrm{kg}$ of protein has been reported to prevent sarcopenia, which is much more than the currently recommended daily dietary protein intake for adults of $0.8 \mathrm{~g} / \mathrm{kg} / \mathrm{day}^{20}$ There is general agreement that the essential amino acid leucine increases protein anabolism and decreases protein breakdown. $^{21}$ Vitamin $\mathrm{D}$ has recently received recognition as another potential intervention strategy for sarcopenia. ${ }^{22,23}$ Three registered clinical trials are currently being conducted across France, Belgium, and the United States to investigate protein nutritional supplements and sarcopenia. All trials include nutritional supplements and resistance training as interventions.

There is growing evidence that physical activity can slow down the loss of skeletal muscle and function. ${ }^{24}$ Exercise also reduces the likelihood of falls and fall-related injuries. ${ }^{24,25}$ While progressive resistance exercises can increase muscle strength and power exercises can increase strength and power, both have been recommended to revert sarcopenia. ${ }^{26-28}$

In Taiwan, the prevalence of sarcopenia has been reported to be $10.8 \%$ in male and $3.7 \%$ in female community-dwelling older Chinese adults aged 65 years or above using EWGSOP criteria. ${ }^{29}$ The impact of sarcopenia on osteoporotic fractures has rarely been reported, however. One study from Japan reported a lower relative skeletal muscle mass index and higher prevalence of sarcopenia in hip fracture patients. ${ }^{30}$ No data are available for Chinese patients.

In this study, we report the prevalence of sarcopenia in Chinese geriatric patients with hip fracture, and its correlation with different factors.

\section{Methods}

This was an observational study to determine the 
prevalence of sarcopenia, which was conducted among geriatric hip fracture patients admitted to Kowloon West Cluster Orthopaedic Rehabilitation Centre in Hong Kong. All patients aged 60 years or above admitted from June to December 2014 to Kowloon West Cluster Orthopaedic Rehabilitation Centre with operated hip fracture were recruited. All study subjects were assessed by a clinician and therapist within 3 weeks of admission. Basic demographics and anthropometric measurement data were collected.

\section{Body composition}

Dual-energy X-ray absorptiometry was adopted to assess sarcopenia. We used the criteria recommended by the Asian Working Group for Sarcopenia (AWGS) based on DXA study. Appendicular and whole lean body mass was measured. Appendicular skeletal muscle mass was normalised by size (sum of lean muscle mass in upper and lower limb divided by square of body height). Relative appendicular skeletal muscle mass index (RASM) was used with a cut-off value of $7 \mathrm{~kg} / \mathrm{m}^{2}$ in men, and $5.4 \mathrm{~kg} / \mathrm{m}^{2}$ in women according to the consensus report of the AWGS. ${ }^{31}$

\section{Strength}

Isometric grip strength, the maximal hand grip strength, was measured using a JAMAR hand dynamometer (Sammons Preston, US). Patients were seated with the shoulders in an anatomical position and elbows in $90^{\circ}$ flexion. The patients were shown how to use the dynamometer and then asked to press for 3 to 5 seconds on the grip using the greatest possible force. The measurement was repeated after a 30-second rest. Both hands were measured separately and the highest score was registered. In order to reduce variability, measurement was taken in a standardised manner. We used $<26 \mathrm{~kg}$ for men and $<18 \mathrm{~kg}$ for women according to the cut-off values recommended by AWGS. ${ }^{31}$

The prevalence of sarcopenia was reported as the mean of RASM and hand grip strength. To find a significant relationship between RASM and other factors (age, hand grip strength, body weight, body height, hip bone mineral density [BMD], and total fat mass), Pearson's correlation was performed in each group. A P value of $<0.05$ was considered statistically significant. Analysis was performed using the Statistical Package for the Social Sciences (Windows version 20.0; SPSS Inc, Chicago [IL], US).

\section{Results}

There were 239 patients (72 men and 167 women) in this study. Their mean age was 82 years, with 81.5 years for males and 82.2 years for females. By stratifying individuals as male or female, the mean ( \pm standard deviation) body weight was $54.1 \pm 9.8 \mathrm{~kg}$ and $48.9 \pm 9.9 \mathrm{~kg}$, respectively. Respective mean hand grip strength was $20.6 \pm 7.3 \mathrm{~kg}$ and $13.6 \pm 4.5 \mathrm{~kg}$. Dualenergy X-ray absorptiometry was performed 14 days (mean; range, 3-28 days) after fall. Using the cut-off value recommended by AWGS, the $95 \%$ centile was lower than the cut-off value (Fig 1). The mean hip BMD for males and females was $0.696 \pm 0.13$ $\mathrm{g} / \mathrm{cm}^{2}$ and $0.622 \pm 0.12 \mathrm{~g} / \mathrm{cm}^{2}$, mean hip T-score was -2.23 and -2.67 , and the mean RASM was $5.72 \pm 0.83$ $\mathrm{kg} / \mathrm{m}^{2}$ and $4.87 \pm 0.83 \mathrm{~kg} / \mathrm{m}^{2}$, respectively (Table 1 ). Age- and sex-specific RASM are shown in Figure 2. For males, RASM declined as age increased. For females, a lower RASM was observed in the youngest and the oldest patients. The prevalence of sarcopenia based on AWGS definition (RASM $<7 \mathrm{~kg} / \mathrm{m}^{2}$ for men and $<5.4 \mathrm{~kg} / \mathrm{m}^{2}$ for women, together with hand grip strength $<26 \mathrm{~kg}$ for men and $<18 \mathrm{~kg}$ for women) was (a)

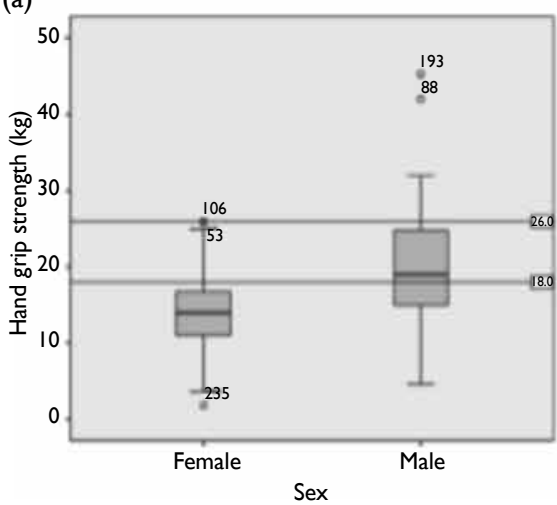

(b)

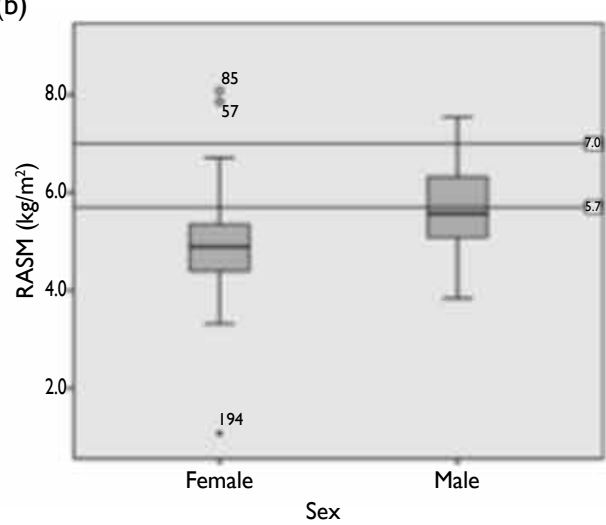

(c)

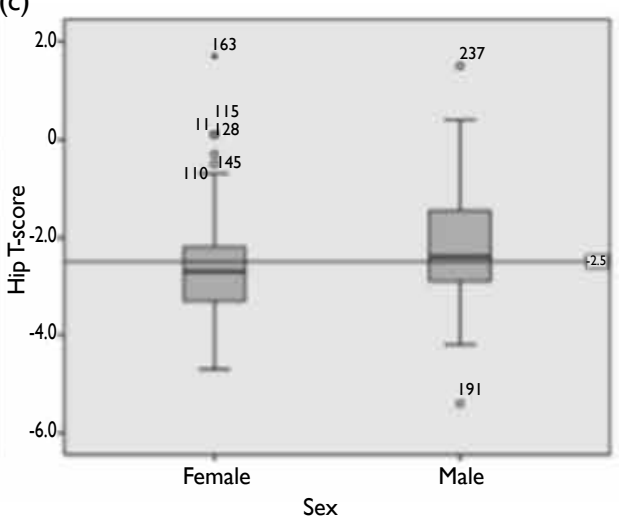

FIG I. Plot of (a) mean hand grip strength, (b) relative appendicular skeletal muscle mass index (RASM), and (c) hip T-score in male and female patients

The horizontal lines within the boxes represent the medians, the lower and upper bounds of the boxes represent the 25th and 75th percentiles, and the I bars represent the 5 th and 95th percentiles; the circles indicate outliners 
TABLE I. Characteristics of participants, body composition, and relative appendicular skeletal muscle mass index (RASM) in both males and females

\begin{tabular}{lcc}
\hline Characteristic & \multicolumn{2}{c}{ Mean (95\% confidence interval) } \\
\cline { 2 - 3 } & \multicolumn{1}{c}{ Male $(\mathbf{n = 7 2 )}$} & Female $(\mathbf{n}=\mathbf{1 6 7 )}$ \\
\hline Age (years) & 54.5 & 82.2 \\
\hline Body weight $(\mathrm{kg})$ & $20.6(18.9$ to 22.3$)$ & $48.9(47.8$ to 51.0$)$ \\
\hline Hand grip strength $(\mathrm{kg})$ & $0.696(0.663$ to 0.729$)$ & $13.6(13.0$ to 14.3$)$ \\
Hip bone mineral density $\left(\mathrm{g} / \mathrm{cm}^{2}\right)$ & $5.72(5.484$ to 5.898$)$ & $0.622(0.603$ to 0.642$)$ \\
RASM $\left(\mathrm{kg} / \mathrm{m}^{2}\right)$ & $-2.23(-2.51$ to -1.95$)$ & $4.87(4.802$ to 5.066$)$ \\
\hline Hip T-score & $20.03(19.21$ to 20.85$)$ & $-2.67(-2.83$ to -2.51$)$ \\
\hline Body mass index $\left(\mathrm{kg} / \mathrm{m}^{2}\right)$ & $12630(10732$ to 14528$)$ & $21.13(20.50$ to 21.78$)$ \\
\hline Total fat mass $(\mathrm{g})$ & & $15695(14569$ to 16821$)$ \\
\hline
\end{tabular}

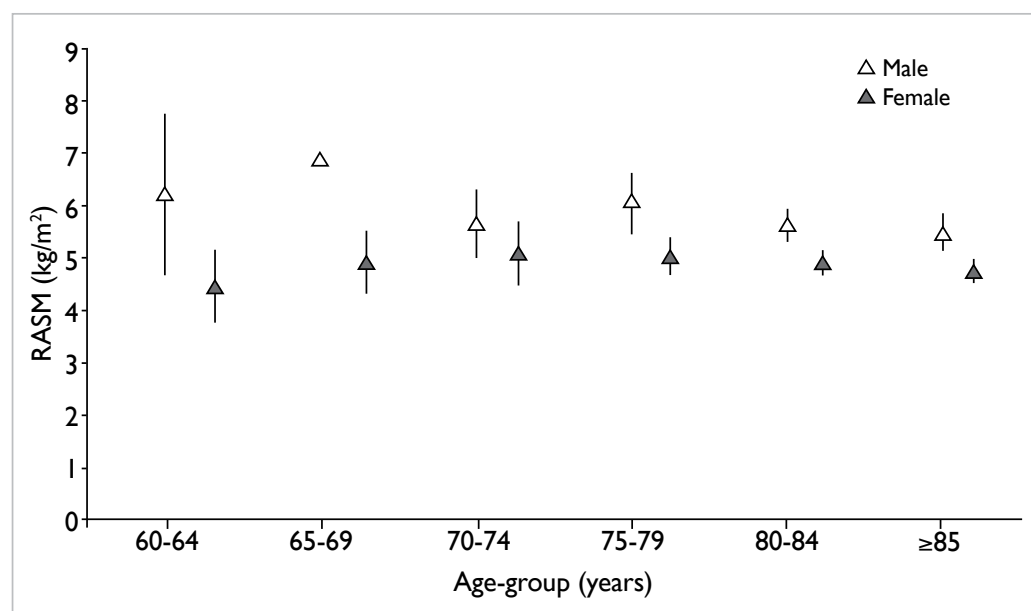

FIG 2. Relative appendicular skeletal muscle mass index (RASM) in different sex and age-group

The triangles indicate the means, and the vertical lines indicate the $95 \%$ confidence intervals

\section{Discussion}

The prevalence of sarcopenia was $10.8 \%$ in male and $3.7 \%$ in female community-dwelling older Chinese adults aged $\geq 65$ years based on AWGS criteria. ${ }^{31}$ Few papers have reported the prevalence of sarcopenia in hip fracture patients, and have used different definitions of sarcopenia. Table $2^{30,32}$ summarises the findings.

Hida et $\mathrm{al}^{30}$ reported the prevalence of sarcopenia in hip fracture patients based on Japanese criterion (appendicular skeletal muscle mass index $<5.46 \mathrm{~kg} / \mathrm{m}^{2}$ in women and $<6.87 \mathrm{~kg} / \mathrm{m}^{2}$ in men): the figures being $44.7 \%$ in males and $81.1 \%$ in females. Di Monaco et a ${ }^{32}$ reported a sarcopenia prevalence of $64 \%$ in female hip fracture patients and $95 \%$ in male hip fracture patients, based on height-adjusted appendicular lean mass (aLM/height $\left.{ }^{2}\right)$. Sarcopenia was defined according to normative data from the New Mexico Elder Health Survey ${ }^{33}$ where aLM was less than 2 standard deviations below the mean of a young reference group. They showed a significant positive correlation between aLM/height ${ }^{2}$ and BMD. ${ }^{32}$

In our study, there was a higher prevalence of sarcopenia in both male and female patients with hip fracture, and even higher than that for community-dwelling older Chinese adults. This reveals that the problem of sarcopenia in geriatric hip fracture patients is very serious. Our study is the only one to adopt the definition proposed by the AWGS and currently accepted in literature for an Asian population. In addition, the interval between fracture and DXA assessment is important: a significant decrease in total body mass, lean mass, and BMD has been reported from 10 days to 2 months post-fracture. ${ }^{34}$ As we performed DXA on an average of 14 days following fall, the potential effect of deterioration in muscle mass after immobilisation was minimised. 

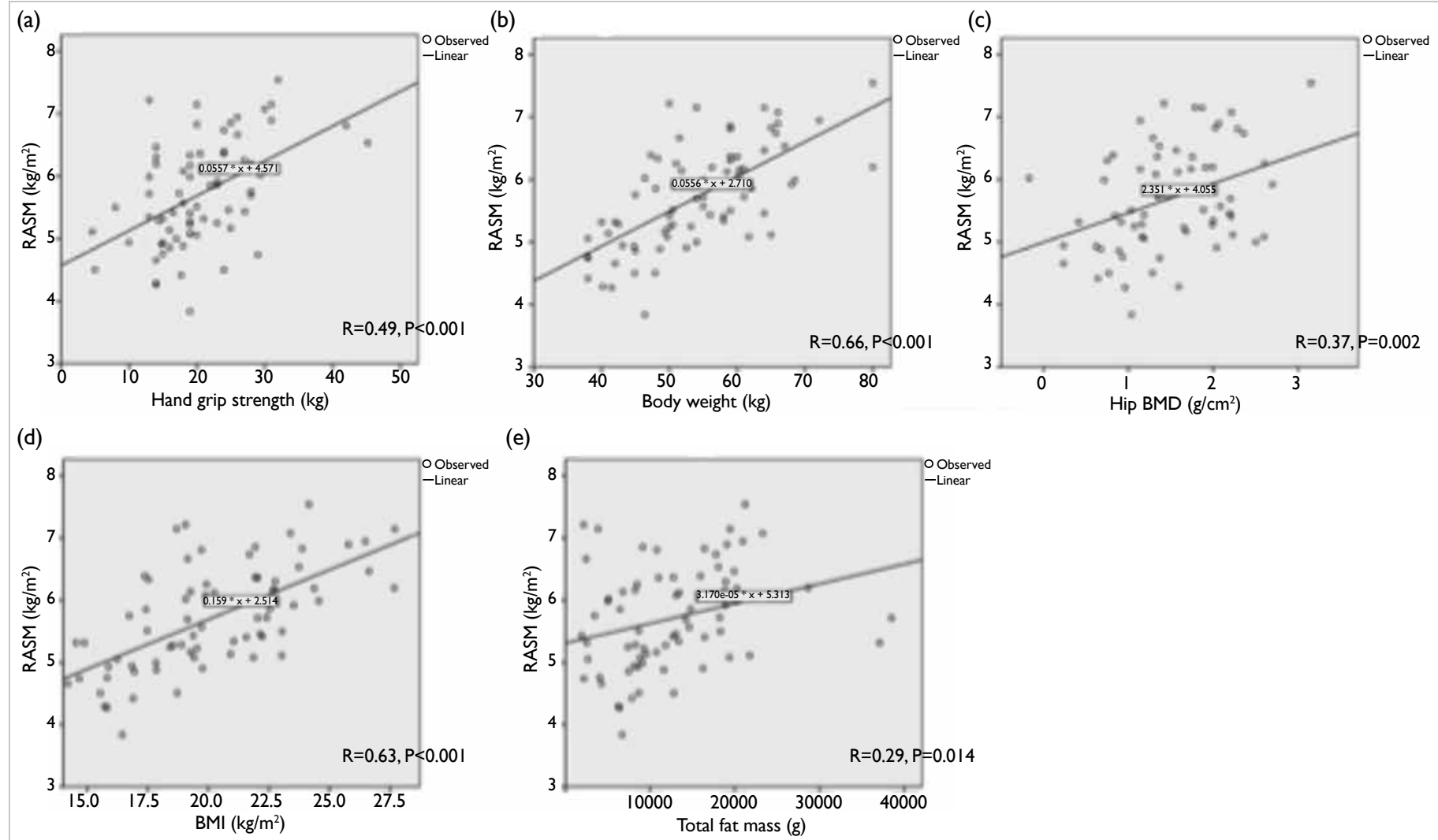

FIG 3. Correlation of relative appendicular skeletal muscle mass index (RASM) and (a) hand grip strength, (b) body weight, (c) hip body mass density (BMD), (d) body mass index (BMI), and (e) total fat mass in male patients

(a)

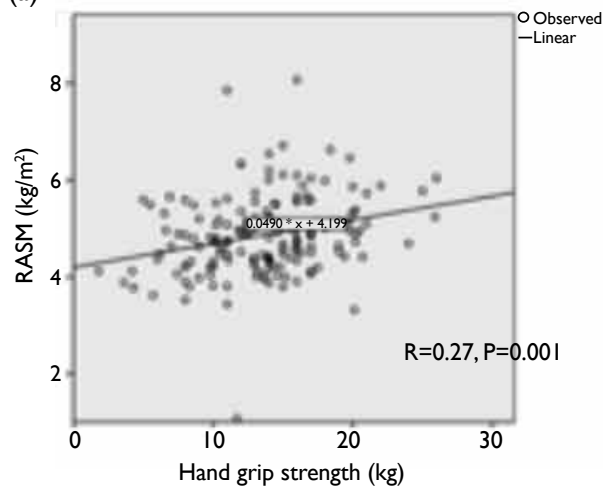

(d)

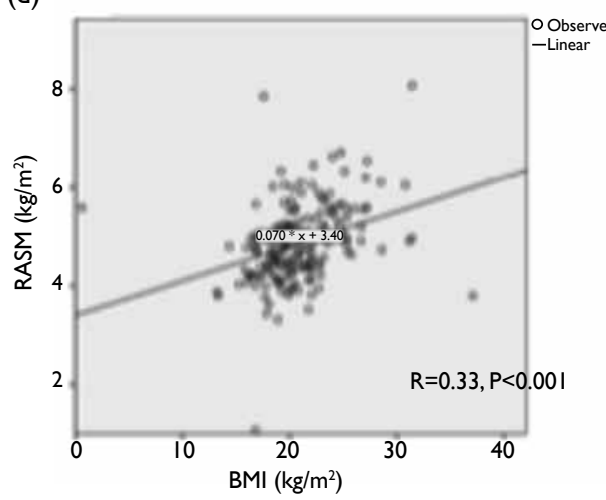

(b)

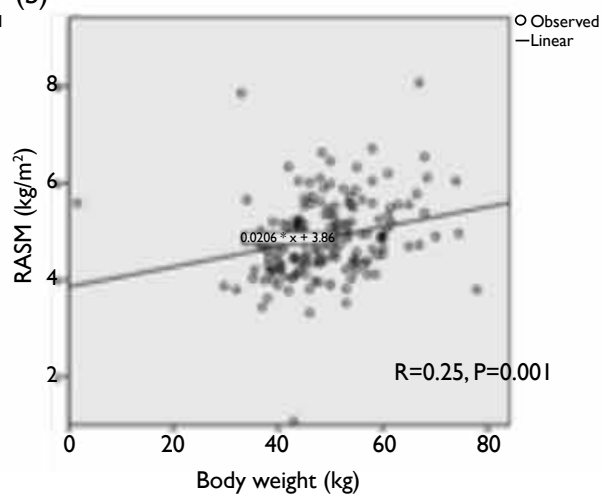

(e)

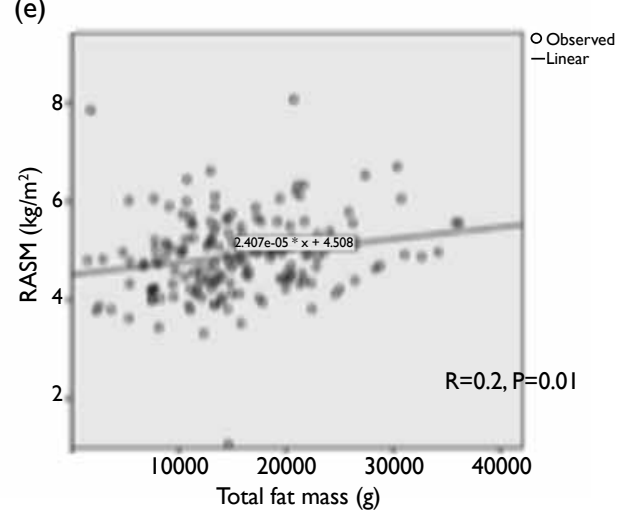

(c)

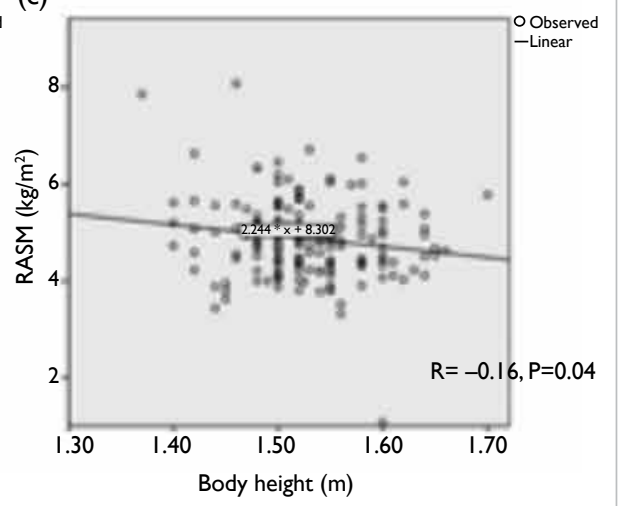

served

FIG 4. Correlation of relative appendicular skeletal muscle mass index (RASM) and (a) hand grip strength, (b) body weight, (c) body height, (d) body mass index (BMI), and (e) total fat mass in female patients 
TABLE 2. Comparison of different studies of sarcopenia in hip fracture patients ${ }^{30,32}$

\begin{tabular}{|c|c|c|c|}
\hline & Hida et al, ${ }^{30} 2013$ & Di Monaco et al, ${ }^{32} 2012$ & Present study, 2015 \\
\hline Prevalence of sarcopenia & $44.7 \%(\mathrm{M}), 81.1 \%(\mathrm{~F})$ & $95 \%(\mathrm{M}), 64 \%(\mathrm{~F})$ & $73.6 \%(\mathrm{M}), 67.7 \%(\mathrm{~F})$ \\
\hline Definition & Japanese criterion & New Mexico Elder Health Survey & AWGS definition \\
\hline $\begin{array}{l}\text { Mean interval between fracture and } \\
\text { DXA assessment (days) }\end{array}$ & $\begin{array}{l}\text { Immediately after fracture and } \\
\text { before surgery }\end{array}$ & 20.9 & 14.2 \\
\hline Mean age (years) & $80.3(\mathrm{M}), 82.7(\mathrm{~F})$ & 79.7 & 82 \\
\hline
\end{tabular}

Abbreviations: AWGS = Asian Working Group for Sarcopenia; DXA = dual-energy X-ray absorptiometry; F = female; $M=$ male

In our study, the mean RASM in females was the lowest in the 60-64 years' age-group. Sarcopenia may be a risk factor in this group of relatively young geriatric hip fracture patients. Further study should assess this particular group of patients to determine the correlation of sarcopenia and fracture risk.

The prevalence of femoral neck osteoporosis based on hip T-score of $<-2.5$ was $47.8 \%$ in males and $59.1 \%$ in females. For male patients the RASM was correlated with hip BMD, although a similar result was not significant in female patients $(R=0.15$, $\mathrm{P}=0.07$ ). The prevalence of both osteoporosis and sarcopenia is high in geriatric hip fracture patients, and the prevalence of sarcopenia is even higher. Based on the high prevalence of both osteoporosis and sarcopenia, screening and treatment of both diseases should be targeted to geriatric patients with hip fracture.

Our study also showed that RASM was correlated with hand grip strength, body weight, and BMI (and total fat mass). Hence, they may be applied to screen for high-risk patients where a whole-body DXA machine or bio-impedance assessment is not available.

There are few potential limitations of our study. First, we only included patients with operated hip fracture. The number of non-operated hip fractures was unknown. Second, the time interval between fall and DXA measurement varied from 3 to 28 days. The period of immobilisation commencement from the date of fracture also varied. As the period of immobilisation lengthens, there will be a drop in RASM, although in our study a non-significant negative correlation between RASM and time interval between fall and DXA measurement was shown. Third, this was an unblinded study, and assessment involved several assessors. Nonetheless, these issues could be minimised by standardising the approach, and providing briefing instructions to the patient being assessed. The use of the DXA machine will not be biased since lean muscle mass is an objective measure.

\section{Conclusion}

Our study showed a high prevalence of osteoporosis and sarcopenia in geriatric patients with hip fracture. With an expanding elderly population, the number of such patients will increase. In addition to surgical treatment of hip fracture, a well-structured screening and treatment programme of osteoporosis and sarcopenia should be implemented in order to reduce subsequent fall, subsequent fracture, and the fracture-related complications and economic burden to Hong Kong.

\section{References}

1. Volpi E, Nazemi R, Fujita S. Muscle tissue changes with aging. Curr Opin Clin Nutr Metab Care 2004;7:405-10.

2. Doherty TJ. Invited review: Aging and sarcopenia. J Appl Physiol (1985) 2003;95:1717-27.

3. Hughes VA, Frontera WR, Roubenoff R, Evans WJ, Singh MA. Longitudinal changes in body composition in older men and women: role of body weight change and physical activity. Am J Clin Nutr 2002;76:473-81.

4. Rosenberg IH. Summary comments. Am J Clin Nutr 1989;50:1231-3.

5. Wu IC, Lin CC, Hsiung CA, et al. Epidemiology of sarcopenia among community-dwelling older adults in Taiwan: a pooled analysis for a broader adoption of sarcopenia assessments. Geriatr Gerontol Int 2014;14 Suppl 1:52-60.

6. Tanimoto Y, Watanabe M, Sun W, et al. Sarcopenia and falls in community-dwelling elderly subjects in Japan: Defining sarcopenia according to criteria of the European Working Group on Sarcopenia in Older People. Arch Gerontol Geriatr 2014;59:295-9.

7. Landi F, Liperoti R, Russo A, et al. Sarcopenia as a risk factor for falls in elderly individuals: results from the ilSIRENTE study. Clin Nutr 2012;31:652-8.

8. Landi F, Liperoti R, Fusco D, et al. Sarcopenia and mortality among older nursing home residents. J Am Med Dir Assoc 2012;13:121-6.

9. Kim JH, Lim S, Choi SH, et al. Sarcopenia: an independent predictor of mortality in community-dwelling older Korean men. J Gerontol A Biol Sci Med Sci 2014;69:124452.

10. Vetrano DL, Landi F, Volpato S, et al. Association of sarcopenia with short- and long-term mortality in older adults admitted to acute care wards: results from the CRIME study. J Gerontol A Biol Sci Med Sci 2014;69:115461.

11. da Silva Alexandre T, de Oliveira Duarte YA, Ferreira Santos JL, Wong R, Lebrão ML. Sarcopenia according to the 
European Working Group on Sarcopenia in Older People (EWGSOP) versus dynapenia as a risk factor for disability in the elderly. J Nutr Health Aging 2014;18:547-53.

12. Janssen I, Shepard DS, Katzmarzyk PT, Roubenoff R. The healthcare costs of sarcopenia in the United States. J Am Geriatr Soc 2004;52:80-5.

13. Janssen I, Heymsfield SB, Ross R. Low relative skeletal muscle mass (sarcopenia) in older persons is associated with functional impairment and physical disability. J Am Geriatr Soc 2002;50:889-96.

14. Heymsfield SB, Gallagher D, Visser M, Nuñez C, Wang ZM. Measurement of skeletal muscle: laboratory and epidemiological methods. J Gerontol A Biol Sci Med Sci 1995;50 Spec No:23-9.

15. Baumgartner RN, Rhyne RL, Troup C, Wayne S, Garry PJ. Appendicular skeletal muscle areas assessed by magnetic resonance imaging in older persons. J Gerontol 1992;47:M67-72.

16. Cruz-Jentoft AJ, Baeyens JP, Bauer JM, et al. Sarcopenia: European consensus on definition and diagnosis: Report of the European Working Group on Sarcopenia in Older People. Age Ageing 2010;39:412-23.

17. Paillaud E, Bories PN, Le Parco JC, Campillo B. Nutritional status and energy expenditure in elderly patients with recent hip fracture during a 2-month follow-up. Br J Nutr 2000;83:97-103.

18. Wyers CE, Breedveld-Peters JJ, Reijven PL, et al. Efficacy and cost-effectiveness of nutritional intervention in elderly after hip fracture: design of a randomized controlled trial. BMC Public Health 2010;10:212.

19. Volkert D, Berner YN, Berry E, et al. ESPEN Guidelines on Enteral Nutrition: Geriatrics. Clin Nutr 2006;25:330-60.

20. Masanes F, Culla A, Navarro-Gonzalez M, et al. Prevalence of sarcopenia in healthy community-dwelling elderly in an urban area of Barcelona (Spain). J Nutr Health Aging 2012;16:184-7.

21. Paddon-Jones D, Rasmussen BB. Dietary protein recommendations and the prevention of sarcopenia. Curr Opin Clin Nutr Metab Care 2009;12:86-90.

22. Morley JE. Sarcopenia: diagnosis and treatment. J Nutr Health Aging 2008;12:452-6.

23. Dawson-Hughes B. Serum 25-hydroxyvitamin D and functional outcomes in the elderly. Am J Clin Nutr
2008;88:537S-540S.

24. Harber MP, Konopka AR, Douglass MD, et al. Aerobic exercise training improves whole muscle and single myofiber size and function in older women. Am J Physiol Regul Integr Comp Physiol 2009;297:R1452-9.

25. Kim HK, Suzuki T, Saito K, et al. Effect of exercise and amino acid supplementation on body composition and physical function in community-dwelling elderly Japanese sarcopenic women: a randomized controlled trial. J Am Geriatr Soc 2012;60:16-23.

26. Waters DL, Baumgartner RN, Garry PJ, Vellas B. Advantages of dietary, exercise-related, and therapeutic interventions to prevent and treat sarcopenia in adult patients: an update. Clin Interv Aging 2010;5:259-70.

27. McCartney N, Hicks AL, Martin J, Webber CE. Longterm resistance training in the elderly: effects on dynamic strength, exercise capacity, muscle, and bone. J Gerontol A Biol Sci Med Sci 1995;50:B97-104.

28. Liu CJ, Latham NK. Progressive resistance strength training for improving physical function in older adults. Cochrane Database Syst Rev 2009;(3):CD002759.

29. Lee WJ, Liu LK, Peng LN, Lin MH, Chen LK; ILAS Research Group. Comparisons of sarcopenia defined by IWGS and EWGSOP criteria among older people: results from the I-Lan longitudinal aging study. J Am Med Dir Assoc 2013;14:528.e1-7.

30. Hida T, Ishiguro N, Shimokata $\mathrm{H}$, et al. High prevalence of sarcopenia and reduced leg muscle mass in Japanese patients immediately after a hip fracture. Geriatr Gerontol Int 2013;13:413-20.

31. Chen LK, Liu LK, Assantachai P, et al. Sarcopenia in Asia: consensus report of the Asian Working Group for Sarcopenia. J Am Med Dir Assoc 2014;15:95-101.

32. Di Monaco M, Castiglioni C, Vallero F, Di Monaco R, Tappero R. Sarcopenia is more prevalent in men than in women after hip fracture: a cross-sectional study of 591 inpatients. Arch Gerontol Geriatr 2012;55:e48-52.

33. Baumgartner RN, Koehler KM, Gallagher D, et al. Epidemiology of sarcopenia among the elderly in New Mexico. Am J Epidemiol 1998;147:755-63.

34. D'Adamo CR, Hawkes WG, Miller RR, et al. Short-term changes in body composition after surgical repair of hip fracture. Age Ageing 2014;43:275-80. 